\section{Toe-to-Heel Air Injection In-situ Combustion Process: Case study from the Azraq Basin, Jordan}

Rudarsko-geološko-naftni zbornik

(The Mining-Geology-Petroleum Engineering Bulletin) UDC: $550: 8$

DOI: 10.17794/rgn.2020.3.8

Professional paper

\author{
Mehaysen Ahmed Al-Mahasneh \\ Jordan-Irbid (Al-Balqa Applied University-Al Huson University College, Chemical Engineering Department), \\ m.mahasneh@bau.edu.jo, ORCID.org/0000-0003-1638-0872.
}

\begin{abstract}
The exploration and drilling operations for oil in the Wadi Rajil region of the Azraq Basin in northeast Jordan confirmed the existence of quantities of asphalt and heavy oil in several formations of limestone and dolomite within layers of sandstone. The estimated area was $1200 \mathrm{~km}^{2}$ (1200oo hectare) and possibly contained 8oo million $\mathrm{m}^{3}$ (five billion barrels) of original oil. The aim of this study is to obtain in-situ combustion and to suggest the application of the drilling of two wells by an in-situ combustion process called Toe-to-Heel Air Injection In-situ Combustion in the Wadi Rajil-Hamzeh field. This approach proposes a pilot project of drilling two wells. One vertical injection well in the upper production zone and another horizontal production well at the bottom of the reservoir. Through this technique, the productivity will increase, the viscosity of the oil will decrease, and consequently the sweep efficiency will be higher. This pilot project's potential production reaches $212.94 \mathrm{~m}^{3} / \mathrm{d}$ of oil. The total time for the project to be completed is around 450 days. The efficiency of recovery in this study reached around 65 to $69 \%$. This result can lead to the possible expansion of the approach applied in this project throughout the Wadi Rajil-Hamzeh region.
\end{abstract}

\title{
Keywords:
}

Toe-to-Heel; Air injection; Heavy Oil; In-situ Combustion; Horizontal well

\section{Introduction}

The demand for oil and the increase in the difficulty of discovering large oil reservoirs, the decrease in reservoirs reserves, and the decrease in oil conventional reserves, have led to an increased interest in heavy oil and tar sands. The predominant factor limiting the economic recovery in such reserves is the high viscosity of the oil in the reservoir. Any decrease in the oil viscosity will lead to an increase in oil movement, thereby improving oil production.

This can be achieved by one of the most effective production methods, which is thermal application in the reservoir.

The fire flooding method is another way to improve oil production and is called Enhanced Oil Recovery (EOR).

The heat can be supplied to the reservoir in the form of hot water, gases, or steam. Heat might be generated in-situ by burning a portion of the oil in the reservoir known as in-situ combustion (ISC). This generated heat ignites oil in formations, leading to the spread of the propagation combustion front through the porous media that contains the oil.

Corresponding author: Mehaysen Al-Mahasneh m.mahasneh@bau.edu.jo
The fuel needed for the continuity of combustion can be supplied from residual materials or from the coke deposited from the combustion zone in process, thermal cracking, pyrolysis, or the combustion front of the oil.

Most in-situ thermal processes use vertical wells for short distances of penetration of the formation, while in horizontal wells, large distances are penetrated. Over the past decade, great progress is achieved in drilling horizontal wells over large distances of around $1000 \mathrm{~m}$.

Horizontal wells provide improved performance over conventional vertical wells, this is primarily due to the expansion of the contact area between the layers of the upper and bottom formation and the horizontal well. This is especially true for thinly stratified formations in which the reservoir is in contact with a larger area of the horizontal well than with the fully penetrated vertical well (Giger et al., 1984). Horizontal wells are strategically placed away from contact with liquids to reduce water/gas coning by causing a decreased displacement and consequent improvement in cumulative oil recovery (Chaperon et al., 1986).

Sweep efficiency during the combustion process is an important factor in the recovery process. Steam drive and cyclic steam stimulation was successfully used in the horizontal wells with the help of steam-assisted gravity drainage to produce heavy oil and oil sands from the reservoir. 
A model was created and various experiments were conducted to verify the effectiveness of the group of a horizontal and a vertical well by steam flooding on the Athabasca sand field, and it was concluded that continuous steam circulation through the perforated horizontal well was effective for producing heavy oil (Greaves et al., 2005).

The Azraq Basin (see Figure 1) is located in the northeast region of the Hashemite Kingdom of Jordan, which includes the region Wadi Rajil-Hamzeh and contains probable reserves of asphalt and heavy oil estimated to be around 800 million $\mathrm{m}^{3}$ (five billion barrels). Figure 1 shows the study area.

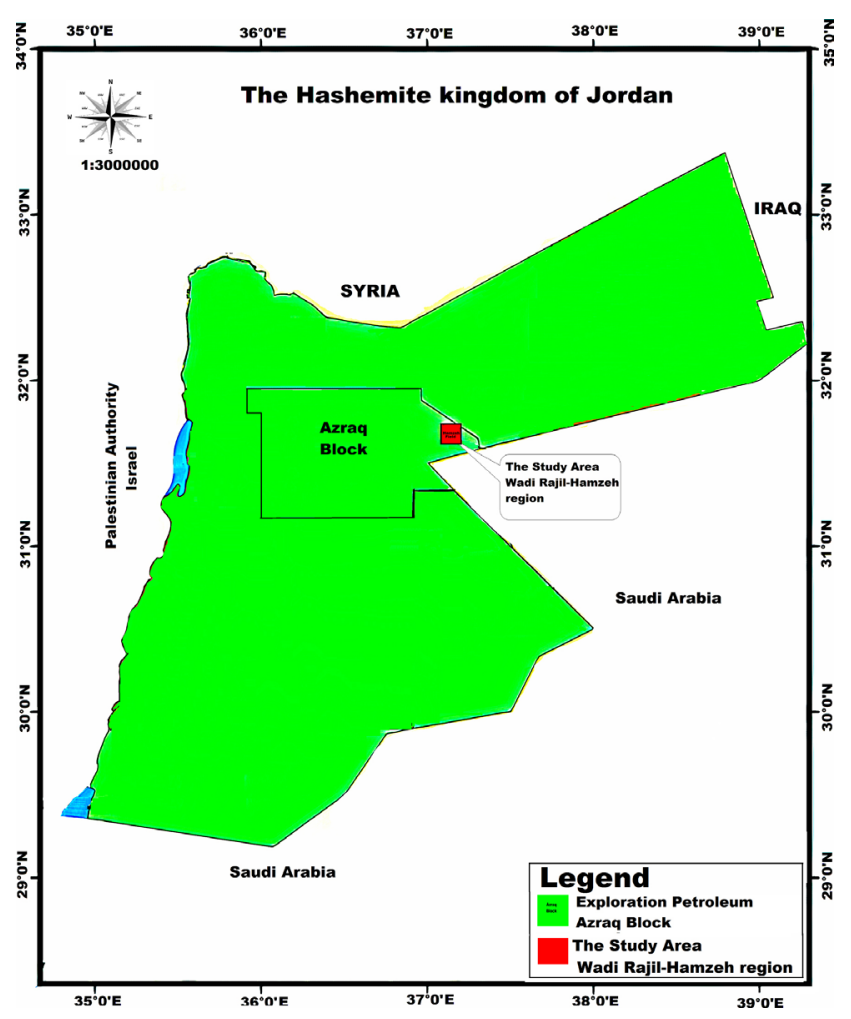

Figure 1: The Hashemite Kingdom of Jordan map, the study area

ISC is a thermal EOR method in which a small fraction of the oil (coke) in the oil layer is burned to mobilise the unburned fraction. Due to the strong exothermic oxidation reactions between hydrocarbon (coke) and oxygen, the temperature of the oil-bearing matrix in the combustion zone reaches 500 to $700^{\circ} \mathrm{C}$, which is much higher than that in steam flood processes $\left(150\right.$ to $\left.250^{\circ} \mathrm{C}\right)$. Higher temperatures are very favourable for tar sands and heavy oil reservoirs because not only is the oil viscosity reduced by several orders of magnitude, but the heavy residue is also thermally cracked to lighter compounds (Xia and Greaves, 2002).

In the conventional ISC process which uses vertical wells for injection and production, the size of the sweep is limited because of the presence of challenges in the layers and excessive work. The toe-to-heel air injection in-situ combustion (ISC) process is a new technology that uses the horizontal wells at the bottom of the reservoir, developed to recover the oil from the heavy oil reservoir, to increase the productivity as well as the sweep efficiency.

\section{Geological settings}

The widespread distribution of bitumen- and asphaltbearing rocks of the Maastrichtian Age in the Azraq region has been clearly established through the drilling of 22 oil wells for exploration in the Wadi Rajil-Hamzeh area. Although bitumen, asphalt and heavy oil are sporadically present through the lithostratigraphy column as shown in Figure 2, the richest occurrences of heavy residual hydrocarbons are found in the Ghareb Formation of Late Cretaceous Age.

\begin{tabular}{|c|c|c|c|c|c|c|}
\hline & AGE & LITHOLOGY & FORMATION & SOURCE & RES. & SEAL \\
\hline & LOCENE & $\tilde{N} \approx \widetilde{\sim} \sim$ & $\begin{array}{l}\text { JORDAN VALLEY } \\
\text { GP. }\end{array}$ & & & \\
\hline & & $\alpha$ & LISSAN SALT & & & \\
\hline & IIOCENE & 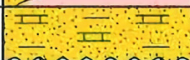 & $\begin{array}{l}\text { JORDAN VALLEY } \\
\text { GP. }\end{array}$ & & & \\
\hline & OCENE & II I I I I & SARA & & & \\
\hline & LEOCENE & IIIIIIII) & TAQIYEH & & & \\
\hline & MAEST. & 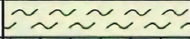 & GHAREB & & & \\
\hline วิ & $\begin{array}{l}\text { CAMP.- } \\
\text { SANT- }\end{array}$ & $\begin{array}{l}1 \\
\end{array}$ & $\begin{array}{l}\text { AMMAN } \\
\text { AZRAQ }\end{array}$ & & & \\
\hline U్ & TURON. & I, I, I, I, & WADI ESSIR & & & \\
\hline 点 & & $\frac{1}{1}$ & $\begin{array}{l}\text { SHUEIB } \\
\text { HUMMAR }\end{array}$ & & & \\
\hline & & & Fuhays Ma'ur & & & \\
\hline & ALBIAN & & KURNUB & & & \\
\hline & $\begin{array}{l}\text { UIDDLE } \\
\text { JRASSIC }\end{array}$ & 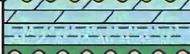 & HUNI & & & \\
\hline & PIACSIC & $\wedge \wedge \wedge \wedge \wedge \wedge \wedge \wedge$ & ABU RUWEIS & & & \\
\hline & KIADSIC & \begin{tabular}{|llll} 
& 1 & 1 & 1 \\
& 1 & 1 & 1 \\
\end{tabular} & MA'IN & & & \\
\hline
\end{tabular}

Figure 2: Lithostratigraphy cross-section of the Hamzeh-Wadi Rajil area

(Qteishat and Mahasneh, 2018)

Using petrophysical logs, descriptions of well site cuttings and core sample analysis indicated that the Ghareb Formation contained dolomite and limestone, described as a light grey fine crystalline, medium hard, with patchy distributions of asphalt and heavy oil.

Figure 3 shows the structure map of the Wadi RajilHamzeh in the Azraq Basin, Table 1 shows the physical and chemical properties of the oil field.

The porosity was described as vuggy to cavernous with fractures and vugs filled with heavy oil. The average thickness of the centre zone of the Ghareb Formation was estimated to be about $29 \mathrm{~m}$.

Accordingly, the drill stem test (DST) was conducted in the bituminous-asphaltic region in the upper zone of the Ghareb Formation. However, the analysis of the core sample taken from a depth of $962 \mathrm{~m}$ in Hamzeh well 4 indicated $24 \%$ water saturation and $76 \%$ residual oil saturation. Thereafter, a second (DST) was conducted in 


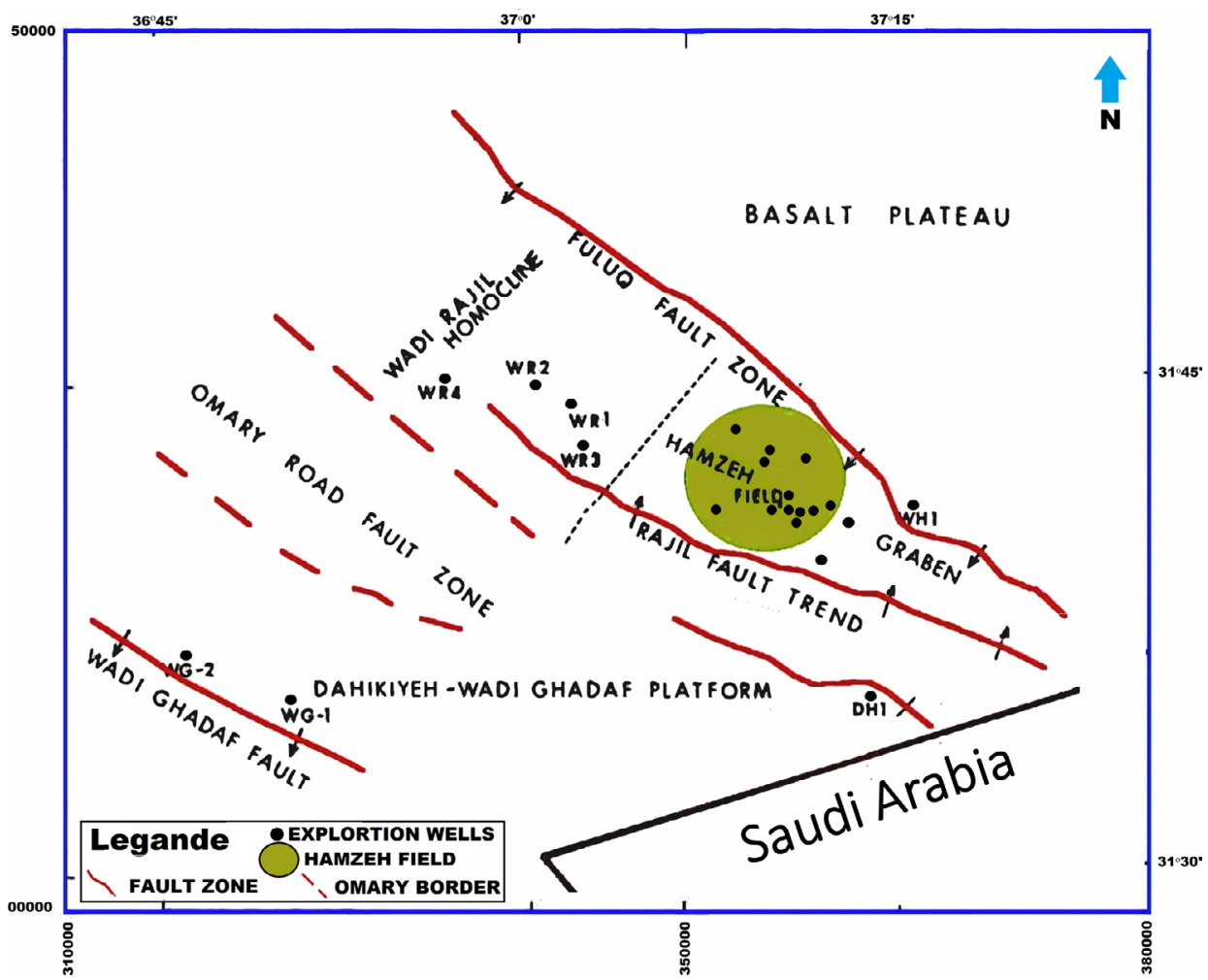

Figure 3: Structure map of Wadi Rajil- Hamzeh in Azraq Basin (Qteishat and Mahasneh, 2018)

the lower Ghareb Formation, which recovered 4 liters of heavy oil from the drill stem.

Table 1: Physical and chemical properties of reservoir

\begin{tabular}{|l|c|c|}
\hline Properties & Unit & Value \\
\hline Average depth & $\mathrm{m}$ & $845-1112$ \\
\hline Gravity of asphalt & API & $9-10^{\circ}$ \\
\hline Gravity heavy oil & API & $17^{\circ}$ \\
\hline Density heavy oil & $\mathrm{gr} / \mathrm{cm}^{3}$ & 0.95 \\
\hline Density of asphalt & $\mathrm{gr} / \mathrm{cm}^{3}$ & $1.0071-1$ \\
\hline Porosity & $\%$ & 18 \\
\hline Permeability & $\mu \mathrm{m}^{2}$ & 592.15 \\
\hline Average thickness & $\mathrm{m}$ & $29-40$ \\
\hline Viscosity & $\mathrm{mPa}-\mathrm{s}$ & $400-1000$ \\
\hline Oil saturation & $\%$ & $45-75$ \\
\hline Reservoir temperature & ${ }^{\circ} \mathrm{C}$ & 40 \\
\hline C/H ratio & $\%$ & 2.58 \\
\hline \multicolumn{2}{|c|}{ Hydrocarbons types } \\
\hline Saturates & wt \% & 4.5 \\
\hline Aromatics & wt \% & 25.2 \\
\hline Sulfur & wt \% & $9.9-11.65$ \\
\hline Melting point of Asphalt & ${ }^{\circ} \mathrm{C}$ & 79 \\
\hline Conradson Carbon & wt \% & 6.1 \\
\hline \multicolumn{2}{|c|}{ Metals } & 80 \\
\hline Nickel & $\mathrm{ppm}$ & 155 \\
\hline Vanadium & $\mathrm{ppm}$ & \\
\hline
\end{tabular}

From the logs, the average porosity for these zones was 13 to $19 \%$. The total thickness of the formation towards the Fuluk Fault zone was in the northeast region. However, the Ghareb Formation found in the northeast of the Wadi Rajil wells WR1, WR2, WR3 and directly to the south of the Hamzeh oil field.

\section{Materials and methods of examination}

\subsection{Device for studying oil oxidation in porous media}

The experimental device for studying oil oxidation in porous media is used to measure the reactivity of different oils in a porous medium. The sample is packed into the cell to be provided with the necessary temperature, pressure, and flow control as shown in Figure 4. The shape of the cell is designed so that the temperature and composition of the reactants is as uniform as possible.

\subsection{Oxidation procedure}

The original core sample containing asphalt and heavy oil was grinded and sieved, thereafter it was packed in the cell and heated to $500^{\circ} \mathrm{C}$ according to the linear program of the time function. The volume of the sample was $32 \mathrm{~cm}^{3}$, and the amount of air flow ranged between 23 and $44 \mathrm{~cm}^{3} / \mathrm{m}^{2}$ per hour.

The device was programmed at a linear heating temperature of $80^{\circ} \mathrm{C} /$ hour, while the average heating temperature of the sample was around 68 to $78^{\circ} \mathrm{C} /$ hour. The 


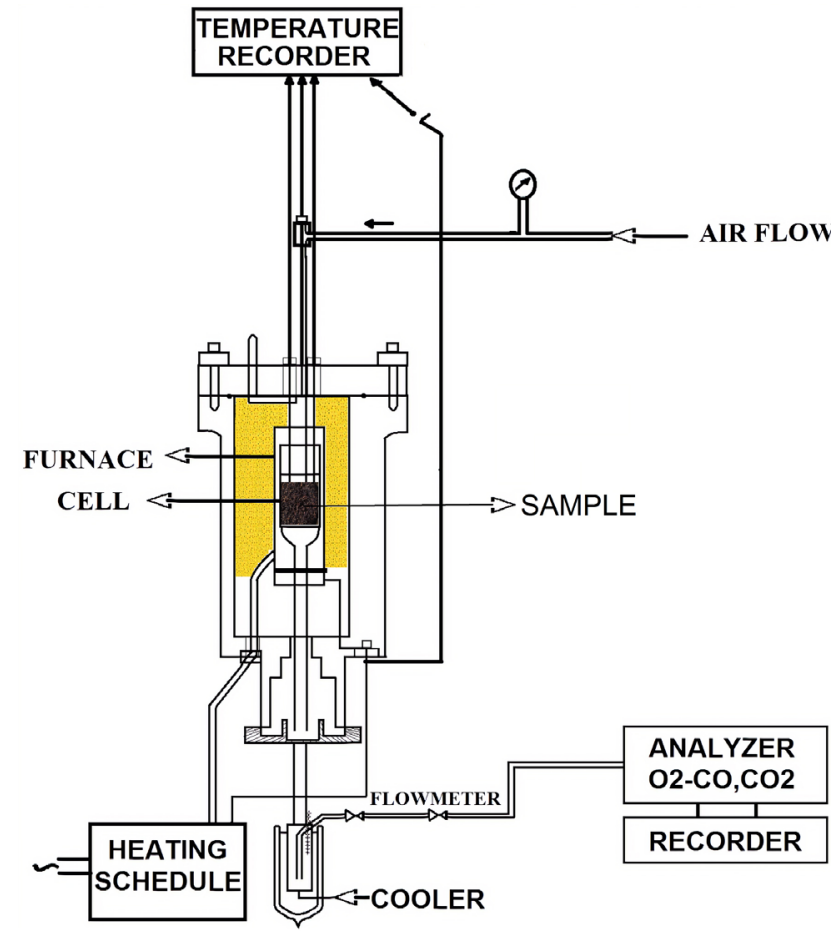

Figure 4: Experimental device for studying oil oxidation in porous media (Burger et al., 1985)

difference between the temperature of the device and average heating temperature of the sample indicates the presence of an interaction within the sample materials with varying temperatures. This provides evidence that the heavy flow of oil under this condition is possible.

Figure 5 shows the results of the heavy oil sample oxidation in the cell and the gases formed as the opera- tion progressed. The non-linear heating temperature of the sample was changing because of the significant interaction within hydrocarbon mixtures in the sample.

The oxygen combustion temperature was between 50 and $190^{\circ} \mathrm{C}$, which was suitable for the continued burning of the oxygen consumed to complete the process successfully. The plateau temperature was 190 to $220^{\circ} \mathrm{C}$.

The amount of $\mathrm{CO}_{2}$ formed after oxidation of the sample at the beginning of the test was very low due to the primary reactions before initiating the combustion which is called low-temperature oxidation (LTO). Due to the continuity reactions to complete the process of

Table 2: Results of the oxidation test.

\begin{tabular}{|l|l|}
\hline The initial temperature of the sample & $22^{\circ} \mathrm{C}$ \\
\hline Final temperature of a sample & $500^{\circ} \mathrm{C}$ \\
\hline Average temperature/hour & $68-78^{\circ} \mathrm{C}$ \\
\hline $\begin{array}{l}\text { The temperature at the beginning } \\
\text { of the oxygen consumption }\end{array}$ & $50-190^{\circ} \mathrm{C}$ \\
\hline $\begin{array}{l}\text { The temperature to form carbon } \\
\text { monoxide }\end{array}$ & $65^{\circ} \mathrm{C}$ \\
\hline $\begin{array}{l}\text { The temperature to form carbon } \\
\text { dioxide }\end{array}$ & $225^{\circ} \mathrm{C}$ \\
\hline carbon dioxide formed & $8.5 \mathrm{vol} \mathrm{\%}$ \\
\hline Carbon monoxide formed & $4.25 \mathrm{vol} \mathrm{\%}$ \\
\hline Oxygen not consumed & $4.1 \mathrm{vol} \mathrm{\%}$ \\
\hline Fuel consumption & $47 \mathrm{~kg} / \mathrm{m}^{3}$ \\
\hline air requirement per $\mathbf{m}^{3}$ of rock & $524 \mathrm{Sm}^{3} / \mathrm{m}^{3}$ \\
\hline Air-to-fuel ratio & $11.15 \mathrm{~m}^{3} / \mathrm{kg} \mathrm{rock}^{3}$ \\
\hline Air-to-oil ratio & $2428 \mathrm{Sm}^{3} / \mathrm{m}^{3}$ \\
\hline
\end{tabular}

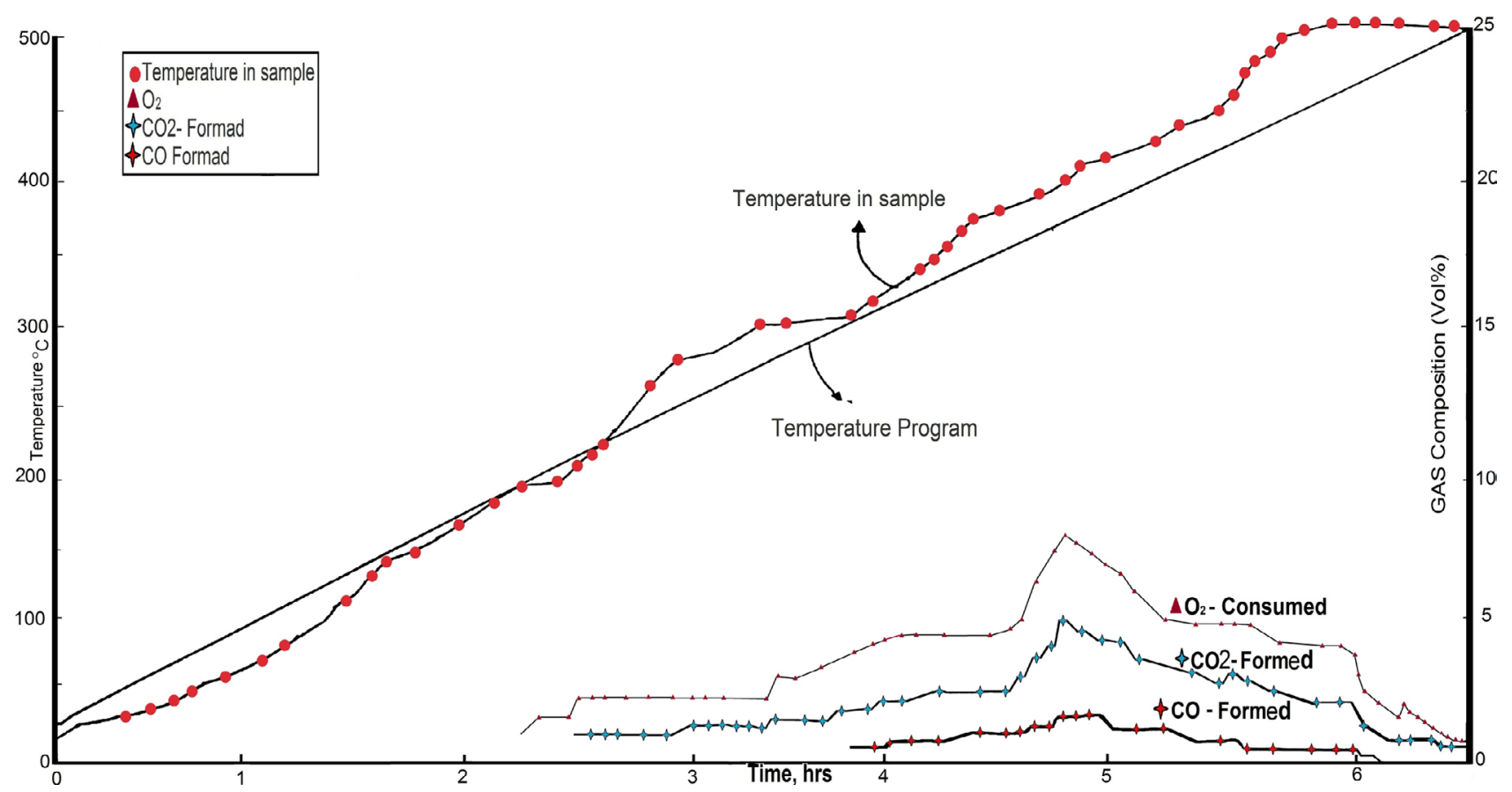

Figure 5: Oxidation of asphalt and heavy oil from the Ghareb Formation 
combustion, the amount of $\mathrm{CO}_{2}$ increased, which is called high-temperature combustion (HTC).

The $\mathrm{CO}$ evaluation showed that the average percentage of $\mathrm{CO}$ was less than $\mathrm{CO}_{2}$, which implies that the combustion process is going forward and will be completed successfully (Mahasneh, 2012).

Table 2 shows the rate of fuel consumption (available fuel) through laboratory tests to be $47 \mathrm{~kg} / \mathrm{m}^{3}$, and this rate might exceed as in the Shannon field with $49 \mathrm{~kg} / \mathrm{m}^{3}$. Moreover, $\mathrm{CO}_{2}$ formed at $225^{\circ} \mathrm{C}$. Experimental data Table 2 shows that the required average air is $524 \mathrm{Sm}^{3} / \mathrm{m}^{3}$ for burning rocks, and the heating value of the fuel is high.

\subsection{Toe-to-heel air injection in-situ combustion process}

The benefits of this modern method are as follows (Turta, 2018):

- Increased control over the ISC front propagation compared to conventional ISC process; ISC front breakthrough always at the toe and progressive advancement towards the heel;

- Easier to implement when heavy oil has some mobility at reservoir conditions, otherwise initial hot communication is needed;

- Easy to implement using existing facilities and horizontal wells (HWs), especially if HWs are placed near the bottom of the oil layer.

\section{Pilot project for ISC from toe-to-heel by air injection (THAI)}

The pilot project includes drilling a vertical well for air injection in the upper reservoir, and a horizontal well for production at the bottom of the reservoir. The application of this technology in-situ, involves the process of combustion in the stable location of the HTC interface from the top to the bottom of the heavy reservoir.

This depends on the vertical and horizontal permeability and porosity of the reservoir for helping the propa-

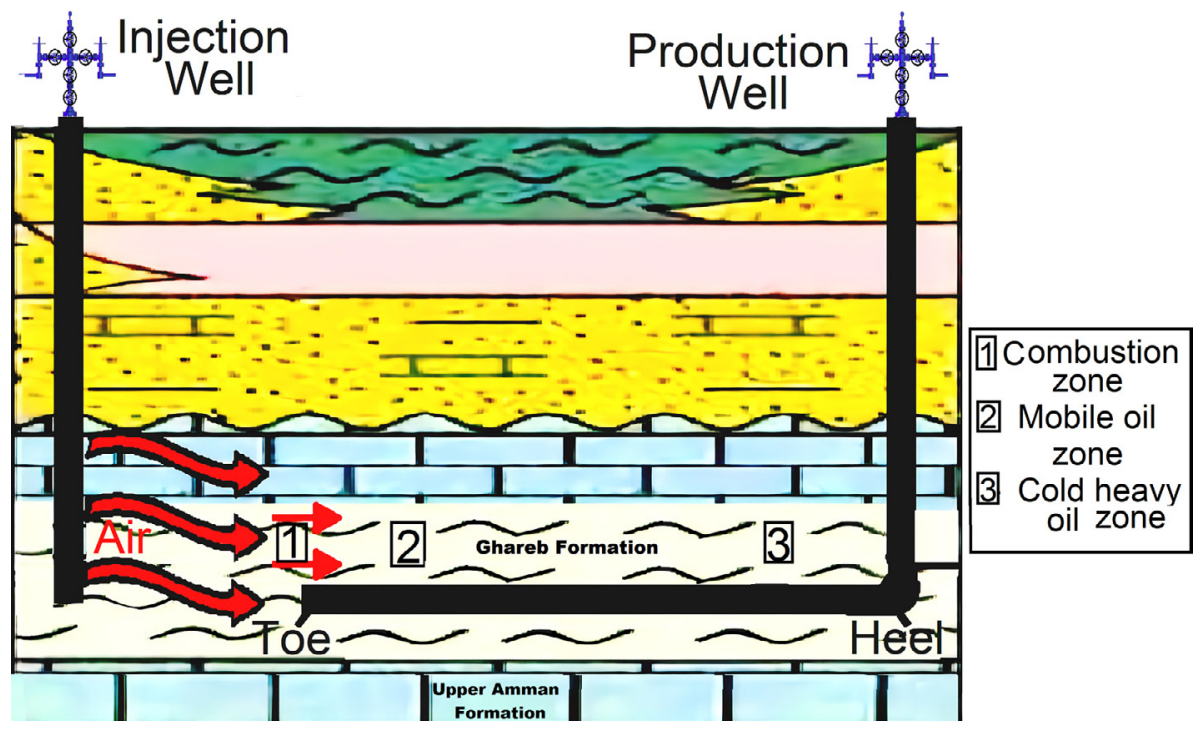

Figure 6: Schematic diagram of the THAI process

Table 3: Design criteria for the pilot project

\begin{tabular}{|l|l|l|l|l|l|}
\hline $\begin{array}{l}\text { Volume of air } \\
\text { injected for the } \\
\text { first stage }\end{array}$ & $6.877 \times 10^{6} \mathrm{Sm}^{3}$ & $\begin{array}{l}\text { Volume of air } \\
\text { injected for the } \\
\text { second stage }\end{array}$ & $17.7 \times 10^{6} \mathrm{Sm}^{3}$ & $\begin{array}{l}\text { Volume of air injected } \\
\text { for the third stage }\end{array}$ & $13.74 \times 10^{6} \mathrm{Sm}^{3}$ \\
\hline $\begin{array}{l}\text { Time required } \\
\text { for the first stage }\end{array}$ & 137 days & $\begin{array}{l}\text { Time required } \\
\text { for the second stage }\end{array}$ & 176 days & $\begin{array}{l}\text { Time required } \\
\text { for the third stage }\end{array}$ & 137 days \\
\hline $\begin{array}{l}\text { Air requirement } \\
\text { per } \mathbf{m}^{3} \text { of rock }\end{array}$ & $524 \mathrm{Sm}^{3} / \mathrm{m}^{3}$ & Air flux & $78.6 \mathrm{Sm}^{3} / \mathrm{m}^{2}$ day & $\begin{array}{l}\text { Compressor horsepower } \\
\text { requirement }\end{array}$ & $3945.12 \mathrm{~kW}$ \\
\hline $\begin{array}{l}\text { Maximum air } \\
\text { injection pressure }\end{array}$ & $4091.349 \mathrm{kPa}$ & Maximum air rate & $100379.2 \mathrm{Sm}^{3} /$ day & $\begin{array}{l}\text { Oil displaced per } \\
\text { unburned reservoir }\end{array}$ & $7560 \mathrm{~m}^{3}$ \\
\hline $\begin{array}{l}\text { Total time for pilot } \\
\text { project }\end{array}$ & $450 \mathrm{days}$ & $\begin{array}{l}\text { Total air for pilot } \\
\text { project }\end{array}$ & $31.44 \times 10^{6} \mathrm{~m}^{3}$ & Oil displaced per burned & $8208 \mathrm{~m}^{3}$ \\
\hline Air oil ratio & $2428 \mathrm{Sm}^{3} / \mathrm{m}^{3}$ & $\begin{array}{l}\text { Overall recovery } \\
\text { efficiency }\end{array}$ & $65 \%$ to $69 \%$ & & \\
\hline
\end{tabular}


gation of the combustion front direction to the horizontal well to provide displacement of the oil from the reservoir. Figure 6 shows a schematic diagram of the THAI process.

Based on the results obtained from the laboratory experiment as shown on Table 2, and the criteria that must be found in the field such as depth, viscosity, porosity, thickness, area, oil saturation, water saturation, fuel deposit, air requirements and the hydrocarbons all lead to the possibility of applying this THAI technology in the formations of the Ghareb in the Wadi Rajil-Hamzeh area in the Azraq Basin.

The amount of fuel produced from the burning zone ranged from medium to high. The amount of fuel consumed increases with the increasing viscosity of oil and saturation of rocks. Based on the results obtained in the field tests globally, the thermal methods can be used to produce heavy oil. Table 3 shows that it is possible to stimulate the reservoir with methods of thermal recovery, such as the ISC process in the Wadi Rajil-Hamzeh area in the Azraq Basin. Table 3 shows the parameters of the design of the THAI ISC process. Several authors have provided procedures for designing the ISC process (Nelson and McNeil, 1961; Parrish et al., 1962; Gates and Ramey, 1980; Fassihi et al., 1981; Sarathi, 1998).

The THAI process burns some oil in the underground sediments in such a way that the residual oil flows to the surface on its own through production wells. The oil displaced for each volume might be produced from the combustion reservoir, heavy oil reservoir, and some unguided areas of the fire front through a combination of gravity and hot gas movement (Tverberg, 2007). Tverberg (2007) indicated that it is expected that THAI will recover $70 \%-80 \%$ of oil originally in the pilot project.

It has been shown that the THAI process can still operate stably for a wide range of reservoir permeabilities and types and degrees of geological heterogeneity. However, the degree of heterogeneity affects the pattern of oxygen utilization, and geological heterogeneity affects fuel concentration and thereby the progression of the combustion front (Ado et al., 2019).

In this study it is possible that THAI will recover 65 to $69 \%$ of the oil originally in the pilot project. This finding coincides with that of (Tverberg, 2007).

\section{Results and discussion}

The experimental laboratory tests helped to obtain the primary in-situ combustion parameters such as fuel requirements, air requirements, reaction peak temperature, oxygen utilization and effluent gas analysis of combustion. These parameters provide the possibility to apply ISC from toe-to-heel air injection (THAI) in the Wadi Rajil-Hamzeh field. The concept of injection through the THAI combustion process involves the production of heavy oil by drilling a vertical injection well at the top of the reservoir and a horizontal production well located along the bottom of the reservoir.

Air is pumped in through the vertical injection well and the combustion front zone is formed which propagates from the injection well towards the horizontal production well from the THAI. The air injection is continued in such a manner that it moves towards the combustion front. The oxygen reacts chemically with oil to provide the coke for combustion. In the beginning of this process, the temperature is low and involves LTO. It increases gradually until it reaches high-temperature oxidation (HTO) in which the combustion reaction is between oxygen and oil in a porous media. The combustion gases that are produced lead to the mobility of fluids downstream until they reach the horizontal production well. A small area of mobile oil is formed ahead of the combustion front. The heavy oil reservoir has a high viscosity of oil in the area far from the combustion front which is called the cold heavy oil zone as shown in Figure 6. The combustion front process continues to progress while maintaining the rate of air injection for the continuity of the process. Table 3 shows that the required air for the project is $31.44 \times 10^{6} \mathrm{~m}^{3}$, and the minimum air flow required to sustain combustion is 78.6 $\mathrm{Sm}^{3} / \mathrm{m}^{2}$ day from the front.

The volume of oil removed per burning is $8208 \mathrm{~m}^{3}$, and the amount of oil produced from the non-combusted reservoir area is $7560 \mathrm{~m}^{3}$. Total oil extraction from the burned and non-burned area is $15768 \mathrm{~m}^{3}$ as we know the productivity of HWs is four to five times more than vertical wells. Furthermore, the air-oil ratio is $2428 \mathrm{Sm}^{3} / \mathrm{m}^{3}$. Considering that the productivity of HWs is between four to five times that of vertical wells, the productivity per day becomes $212.94 \mathrm{~m}^{3}$. Based on these results of the laboratory experiment, they can lead us to apply the project in the future to produce oil from the study area.

\section{Conclusion}

- Through exploratory wells, the presence of heavy and asphalt oil was demonstrated in Wadi RajilHamzeh-Wadi Al Ghadaf area in the formations of the Ghareb (Maastrichtian) and Upper Amman, (Campanian-Santonian) region.

- Formations of these deposits of hydrocarbons range from 680 to $1650 \mathrm{~m}$ in the Ghareb and from 1310 to $2040 \mathrm{~m}$ in Upper Amman Formation.

- Accumulation of hydrocarbons showed an uneven distribution, from small spots to cracks and cavities filled with asphalt and heavy oil and were directly connected with the porosity and cracks of the collected rocks. Reservoir rock limestone, dolomite, and sandstone interferences were found because of the repeated number of core samples extracted from different wells which showed hydrocarbons. 
- The analysis of oil and asphalt showed that the asphalt contained a sulphur content in the range from $9.92 \%$ to $11.65 \%$ with a melting point of $79^{\circ} \mathrm{C}$.

- The amount of the original hydrocarbons present is probably 800 million $\mathrm{m}^{3}$ (five billion barrels).

- Based on laboratory experiments with the oxidation cell device, the design criteria were obtained for a pilot project with thermal conditions THAI, which can be applied when drilling a vertical well for injection and another horizontal well for production.

- The productivity of HWs is four to five times more than in vertical wells; furthermore, the air oil ratio is $2428 \mathrm{Sm}^{3} / \mathrm{m}^{3}$.

- The production rate of oil is $47.32 \mathrm{~m}^{3} /$ day. Given that the productivity of HWs is between four to five times that of vertical wells, it implies that productivity per day becomes $212.94 \mathrm{~m}^{3}$.

\section{References}

\section{Papers:}

Ado, M.R., Greaves, M. and Rigby, S. (2019): Numerical simulation of the impact of geological heterogeneity on performance and safety of THAI heavy oil production process. Journal of Petroleum Science and Engineering, 173, 1130-1148. doi:org/10.1016/j.petrol.2018.10.087.

Chaperon, I. (1986): Theoretical Study of Coning Toward Horizontal and Vertical Wells in Anisotropic Formations: Subcritical and Critical Rates. SPE Annual Technical Conference and Exhibition, 5-8 October, New Orleans, Louisiana, Society of Petroleum Engineers. doi: org/10.2118/ 15377-MS.

Gates, C. and Ramey Jr, H. (1980): A Method for Engineering In-Situ Combustion Oil Recovery Projects. Journal of Petroleum Technology, 32(02), 285-294. doi:org/10.2118 17149-PA.

Giger, F., Reiss, L. and Jourdan, A. (1984): The Reservoir Engineering Aspects of Horizontal Drilling. SPE Annual Technical Conference and Exhibition, 16-19 September, Houston, Texas, Society of Petroleum Engineers. doi: org/10.2118/13024-MS.

Greaves, M., Xia, T. and Ayasse, C. (2005): Underground Upgrading of Heavy OIl Using THAI- 'Toe-to-Heel Air
Injection'. SPE International Thermal Operations and Heavy Oil Symposium, 1-3 November, Calgary, Alberta, Canada, Society of Petroleum Engineers. doi: org/10.2118 /97728-MS.

Mahasneh, M. (2012): Determine factors affecting fuel availability and composition by cell oxidation during laboratory test for in-situ combustion. Contemporary Engineering Sciences, 5(4), 171-188.

Parrish, D., Rausch, R., Beaver, K. and Wood, H. (1962): Underground Combustion in the Shannon Pool, Wyoming. Journal of Petroleum Technology; Society of Petroleum Engineers, 14(02), 197-205. doi:org/10.2118/141-PA

Qteishat, A. and AL-Mahasneh, M.A. (2018): Hydrocarbons Potential in the Azraq Area. Open Journal of Geology, 8, 753-763. doi.org/10.4236/ojg.2018.88044.

Xia, T. and Greaves, M. (2002): Upgrading Athabasca Tar Sand Using Toe-to-Heel Air Injection. Journal of Canadian Petroleum Technology, 41(08), 51-57. doi: org/10.2118/0208-02.

\section{Books/thesis:}

Burger, J., Sourieau, P. and Combarnous, M. (1985): Thermal methods of oil recovery (Vol. First). Gulf Publishing Company, Book Division, $430 \mathrm{p}$.

Fassihi, M., Gobran, B. and Ramey, H. (1981): Algorithm for computing in-situ combustion oil recovery performance. United States: Stanford Univ., CA (USA). Petroleum Research Inst, $29 \mathrm{p}$.

Nelson, T., and J.S. McNeil. (1961): How to engineer an insitu combustion project; New York. lecture presented at University of Texas, $31 \mathrm{p}$.

Sarathi, P. (1998): In-Situ Combustion Handbook-Principles and Practices. Tulsa, United States: National Petroleum Technology Office, 423 p. doi:10.2172/3175.

\section{Internet sources:}

URL1: Turta, A. (2018). Toe-To-Heel Air Injection (THAI) Process. Retrieved from In-Situ Combustion (ISC), ALEX TURTA'S WEBSITE: https://www.insitucombustion.ca/ Advanced_THAI_Brochure.pdf (accessed October 2018).

URL2: Tverberg, G. (2007, August 28). Extracting Heavy Oil: Using Toe to Heel Air Injection (THAI). Retrieved from The Oil Drum:Canada: http://theoildrum.com/node/2907 (accessed October 2018). 


\section{SAŽETAK}

\section{Proces Toe-to-Heel utiskivanja zraka za in-situ spaljivanje nafte u ležištu: primjer iz bazena Azraq, Jordan}

Tijekom istraživačkih i bušaćih aktivnosti u regiji Wadi Rajil (bazen Azraq) na sjeveroistoku Jordana utvrđeno je postojanje određenih akumulacija asfalta i teške sirove nafte u nekoliko litotipova vapnenca i dolomita unutar slojeva pješčenjaka. Potencijalne rezerve nafte iznose 800 milijuna $\mathrm{m}^{3}$ (pet milijardi barela) te zahvaćaju površinu od približno 1200 $\mathrm{km}^{2}$ (120 ooo hektara). Cilj ove studije bio je istražiti mogućnost primjene procesa Toe-to-Heel utiskivanja zraka za insitu spaljivanje nafte u ležištu na polju Wadi Rajil-Hamzeh, za čije je provođenje predviđena izrada dviju novih bušotina. U sklopu pokusnoga projekta izradile bi se dvije nove bušotine, odnosno jedna okomita (utisna) bušotina kojom bi se zahvatilo područje bliže krovini ležišta te vodoravna (eksploatacijska) bušotina koja bi bila položena bliže podini ležišta. Primjenom ove tehnologije povećala bi se proizvodnost iz spomenutoga ležišta, smanjila bi se viskoznost nafte te bi se povećao koeficijent obuhvata ležišta istiskivanjem. Pokusnim projektom predviđeno je pridobivanje i do $212,94 \mathrm{~m}^{3}$ nafte na dan. Ukupno je predviđeno vrijeme za provedbu pokusnoga projekta približno 450 dana, a procijenjeno je da se njegovom primjenom može ostvariti iscrpak od 65 do $69 \%$. Dobiveni rezultati upućuju na mogućnost proširenja primjene iste tehnologije na cijelo područje Wadi Rajil-Hamzeh.

\section{Ključne riječi:}

Toe-to-Heel, utiskivanje zraka, teška sirova nafta, in-situ spaljivanje, horizontalna bušotina 